History and Society in Central America 
Translations from Latin America Series

Institute of Latin American Studies

University of Texas at Austin 


\section{History and Society in Central America}

\section{By}

Edelberto Torres Rivas

Translated by

Douglass Sullivan-González

ד University of Texas Press, Austin 
Copyright (C) 1993 by the University of Texas Press

All rights reserved

First Edition, 1993

Requests for permission to reproduce material from this work should be sent to Permissions, University of Texas Press, P.O. Box 7819, Austin, Texas 78713-7819

(6) The paper used in this publication meets the minimum requirements of American National Standard for Information Sciences-Permanence of Paper for Printed Library Materials, ANSI Z39.48-1984.

\section{Library of Congress Cataloging-in-Publication Data}

Torres-Rivas, Edelberto.

[Interpretación del desarrollo social centroamericano. English]

History and society in Central America / by Edelberto Torres-Rivas ; translated by Douglass Sullivan-González.

p. cm. - (Translations from Latin America Series)

Includes bibliographical references and index.

ISBN 0-292-78128-8 (cloth). — ISBN 0-292-78131-8 (pbk.)

1. Central America-Economic conditions. 2. Central America-Social conditions. 3. Central America-Economic integration. I. Title. II. Series.

HC141.T6713 1993

93-5974

$330.9728^{\prime} 052-\mathrm{dc} 20$

CIP 